\title{
Finite Element Analysis of Bearing Capacity of RC Beams Retrofitted with External Bars
}

\author{
G. Vasudevan ${ }^{a}$ and S. Kothandaraman ${ }^{b}$ \\ a Perunthalaivar Kamarajar Institute of Engineering and Technology, Karaikal, India \\ ${ }^{\mathrm{b}}$ Pondicherry Engineering College, Puducherry, India
}

УДК 539.4

\section{Исследование несущей способности железобетонных балок, армированных наружными стержнями, с помощью метода конечных элементов}

\author{
Г. Васудеван ${ }^{\mathrm{a}}$, С. Котхандараман

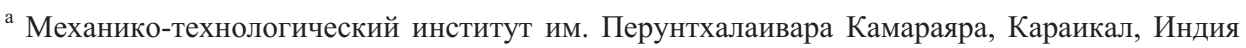 \\ ${ }^{\sigma}$ Технический колледж г. Пудучерри, Индия
}

Одним из экономически эффективных и простых способов повышения прочности при изгибе является укрепление балки с помощью наружных стержней на уровне ее нижней поверхности. Обсуждаются моделирование методом конечных элементов и нелинейный анализ железобетонных балок с дополнительными арматурными стержнями, выполненные на базе программного комплекса ANSYS 12.0. Моделирование методом конечных элементов железобетонных балок проводилось на основе дискретного моделирования армирования. Полученные данные сравнивались с результатами экспериментальных исследований 20 образцов балки при четырехточечном изгибе. Для моделирования балки методом конечных элементов использовались элементы SOLID65, SOLID45 и LINK8. Наличие упругих элементов COMBIN39 позволило смоделировать контакт трения между нижней поверхностью балки и наружными стержнями. Результаты исследований изогнутой формы балки, изменения деформации по ее длине и глубине, а также распространение трещины на разных стадиях нагружения представлены в виде широкодиапазонного графического дисплея с помощьью командного файла с использованием комплекса параметрического проектирования ANSYS.

Ключевые слова: наружные стержни, программный комплекс ANSYS, элемент COMBIN39.

Introduction. Strengthening of existing reinforced concrete (RC) structures is of prime importance in the current scenario due to the reasons such as to safeguard the non-engineered buildings, and upgrade the vulnerable buildings to current seismic codes, Retrofitting of existing buildings is always preferred over demolition and reconstruction so as to reduce the consumption of raw materials and mitigate the global warming problems. The existing strengthening methods, such as section enlargement, bonded steel plating, external post-tensioning and fiber reinforced polymer (FRP) composites wrapping, have demerits, such as high cost, loss of aesthetics, increase in self-weight, need for careful surface preparation, unexpected delamination failure, etc. The external reinforcement technique proposed by the authors [1] has advantages such as speed and simplicity of installation; minimal disruption during installation; use of cost effective materials; greater cross-sectional area of external bars when compared to prestressed tendons makes it less susceptible to corrosion, vandalism and sabotage; minimal surface preparation of concrete substrate; no delamination failure problems, as experienced in bonded plates and FRP laminates $[2,3]$. In this paper, results of the nonlinear finite element (FE) analysis of twenty 
numbers of RC beams are presented and validated using the experimental results reported elsewhere. The nonlinear behavior of RC beams with external bars is quite complicated due to the involvement of heterogenic and cracking behavior of concrete. Also, modeling of external bars at the soffit level anchored at the ends is different from the conventional reinforcing bars due to lack of bonding at the soffit level. The finite element modeling is carried using SOLID65, SOLID45, LINK8, and COMBIN39 elements [4].

1. Review of Literature. Experimental testing on the flexural behavior of RC beams has been carried out by Buckhouse [5], and the critical results were compared with analytical values. Wolanski [6] has carried out the finite element analysis (FEA) using ANSYS for the experimental beams provided by Buckhouse [5] and validated the results. He has used SOLID65, SOLID45, and LINK8 elements to model concrete, steel cushion at the supports and loading points using one quarter of the beam model. The steel reinforcements were incorporated in the concrete elements through the nodes created by the mesh of the concrete volume. Boundary conditions were applied at points of symmetry, and at the supports. Kachlakev et al. [7] studied the behavior of RC beams with externally bonded carbon fiber reinforced polymer (CFRP) fabric using ANSYS. They followed smeared cracking approach for FE modeling using SOLID65 for concrete, LINK8 for rebar, SOLID46 for FRP composites and SOLID45 for steel plates at the supports and loading points. Fanning [8] conducted FEA on $3.0 \mathrm{~m} \mathrm{RC}$ beams and $9.0 \mathrm{~m}$ post-tensioned concrete beams with ANSYS V5.5 using smeared crack model to allow for concrete cracking with the option of modeling the reinforcement in a distributed or discrete manner. Suggested that for RC beams internal reinforcement should be modeled discretely and for post-tensioned beams the post-tensioning tendons should be modeled discretely with any other additional reinforcement modeled in a distributed manner. Also stated that, the Young modulus and concrete tensile strength used in the numerical models can be calculated using the existing rules of thumb from the known compressive strength of concrete.

Dahmani et al. [9], studied the crack propagation in RC beams using ANSYS modeled with SOLID65 element with smeared reinforcement approach, in which the concrete and the reinforcing were incorporated into elements with the same geometrical boundaries and the effects of reinforcing were averaged within the pertaining element. Based on the results, they stated that, in spite of the relative simplicity of the employed models, satisfactory predictions of the response were obtained. Travarez [10] discussed the merits and demerits of discrete model, embedded model and smeared model for incorporating reinforcements depending on the type of system. Advantages ANSYS parametric design language (APDL) and batch mode approach for conducting multiple analysis was studied and discussed by Vasudevan and Kothandaraman [11]. Sallam et al. [12] presented the numerical simulation of peeling failure of FRP strengthened flexural beams using ANSYS and stated the discrete crack approach was more accurate than smeared crack approach in simulating the peeling crack. Elavenil and Chandrasekar [13] presented the numerical models to predict the flexural behavior of RC beams strengthened with ferro-cement. The general behavior of the FE models represented by the load-deflection plots at mid-span showed good agreement with the experimental and theoretical results. The FE models showed slightly more stiffness than the test data ranges due to the exclusion of bond slip (between the concrete and steel reinforcing) and micro cracks occurring in the actual beams in the model. Santhakumaret et al. [14] presented numerical study on unretrofitted and retrofitted reinforced concrete beams subjected to combined bending and torsion using ANSYS and revealed that the CFRP composites with $\pm 45^{\circ}$ fiber orientations were more effective in retrofitting the $\mathrm{RC}$ beams subjected to combined bending and torsion for higher torque to moment ratios. A detailed parametric study on nonlinear FEA on RC beams was conducted by Vasudevan and Kothandaraman [15] with regard to mesh density, material modeling, effect of excluding shear reinforcements in flexural behavior, inclusion of steel cushion at the supports and loading points. 
2. Beam Specimens under Study. Six control beams (RF-N-X, RF-H-X) and fourteen retrofitted beams (ER-N-X-Y, ER-H-X-Y) with external bars at the soffit level are used for the FEA and the results are compared with test results. Beam specimens of size $2000 \times 250 \times 200 \mathrm{~mm}$ with an effective span of $1800 \mathrm{~mm}$ for two grades of concrete designated as $\mathrm{N}$ and $\mathrm{H}$ with targeted cube compressive strength of 30 and $40 \mathrm{MPa}$ was used for the investigation. The clear cover of $25 \mathrm{~mm}$ for the experimental testing and effective cover $31.25 \mathrm{~mm}$ for FE modeling was used for beams. The beams were tested for four-point bending with loading at a distance of $550 \mathrm{~mm}$ from either end of the support, so as to have a moment span of $700 \mathrm{~mm}$. The detailed report on the experimental investigation on the behavior of RC beams with external bars at the soffit is to be reported elsewhere. The details and other parameters used for the study are shown in Fig. 1 and Table 1.

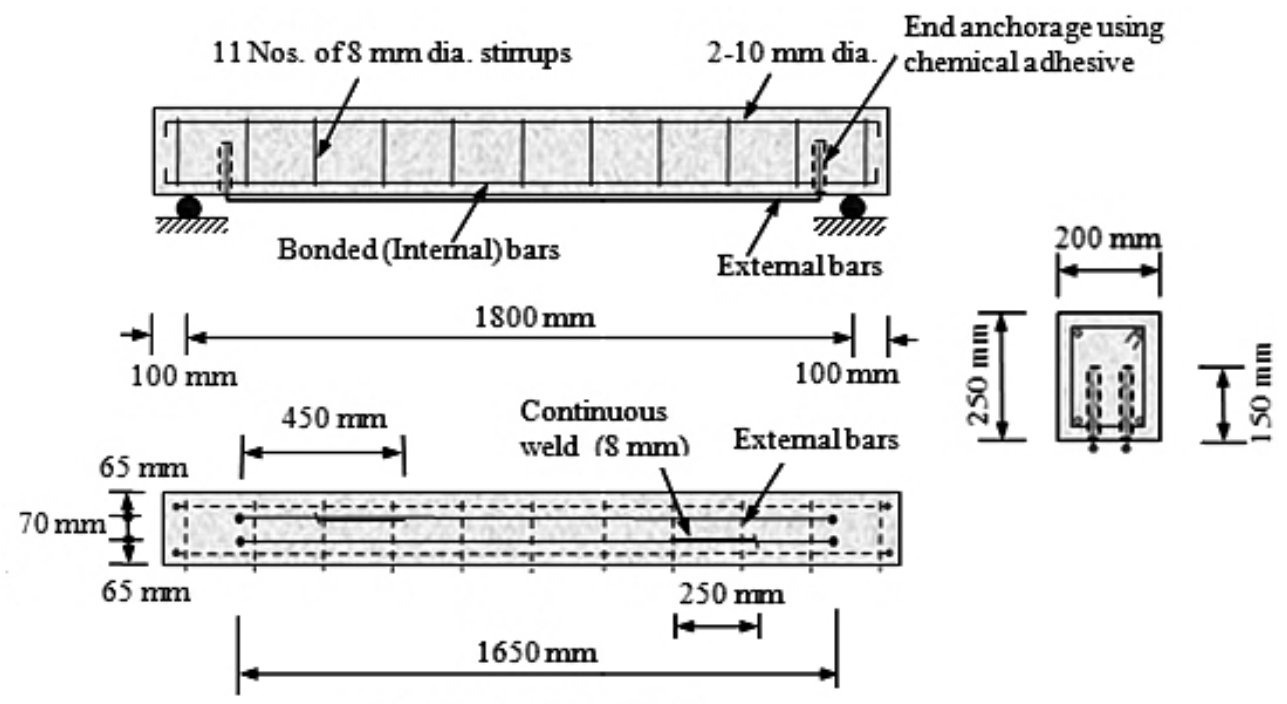

Bottom view (soffit level)

Fig. 1. Details of beam specimen.

3. Finite Element Modeling and Analysis Using ANSYS. RC beam specimens were modeled using eight nodes SOLID65 element with three degrees of freedom at each node (translations in the nodal $x, y$, and $z$ directions), capable of handling nonlinear behavior, cracking in three orthogonal directions due to tension, crushing in compression and plastic deformation. The reinforcing bars were incorporated in the concrete model using two nodes LINK8 spar element with three degrees of freedom at each node (translations in the nodal $x, y$, and $z$ directions), capable of handling plasticity, creep, swelling, stress stiffening and large deflection. The supports and loading points were modeled as steel cushion to avoid stress concentration problem using eight nodes SOLID45 element with three degrees of freedom at each node (translations in the nodal $x, y$, and $z$ directions), which handles plasticity, creep, swelling, stress stiffening, large deflection and strain. The contact between external bars and the soffit of the beam is modeled using COMBIN39, a unidirectional element with nonlinear generalized force-deflection capability. One-quarter of the beam was modeled for the FEA due to symmetry as shown in Fig. 2. Material model for concrete used for the study is derived from IS 456: 2000 [16] with a partial safety factor of 1.0. Other parameters used for the modeling is furnished in Tables 1 and 2. Parameters which are not stated in this report were taken as program default. The FE modeling was carried out in batch mode in sequence using KEYPOINTS, LINES, LESIZE, VOLUME, VMESH and VSWEEP commands. The rebar elements were introduced in the nodes of the concrete 


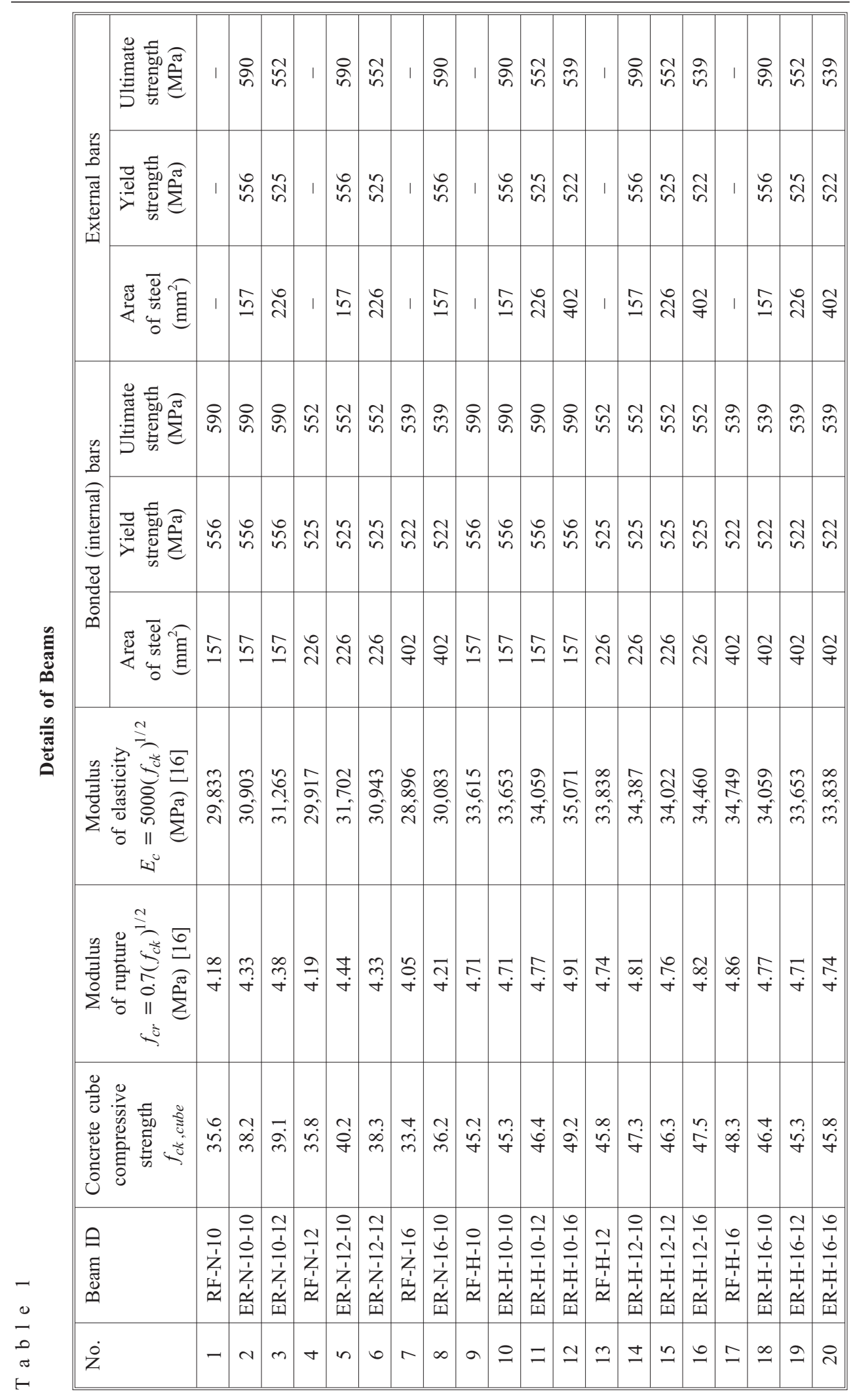


$\mathrm{T}$ a b 1 e 2

Materials Properties for Concrete and Steel

\begin{tabular}{||l|c|l|c||}
\hline \multicolumn{1}{|c|}{ Property } & Value & \multicolumn{1}{|c||}{ Property } & Value \\
\hline Yield strength of hanger bars $(\mathrm{MPa})$ & 556 & Shear transfer coefficient for open crack & 0.3 \\
\hline Yield strength of stirrups $(\mathrm{MPa})$ & 550 & Shear transfer coefficient for closed crack & 1.0 \\
\hline Tangent modulus for steel $(\mathrm{MPa})$ & 20 & Uniaxial crushing stress value & -1.0 \\
\hline Poisson's ratio of concrete & 0.2 & Stiffness multiplier constant $\left(T_{c}\right)$ & 0.6 \\
\hline Poisson's ratio of steel & 0.3 & & \\
\hline
\end{tabular}

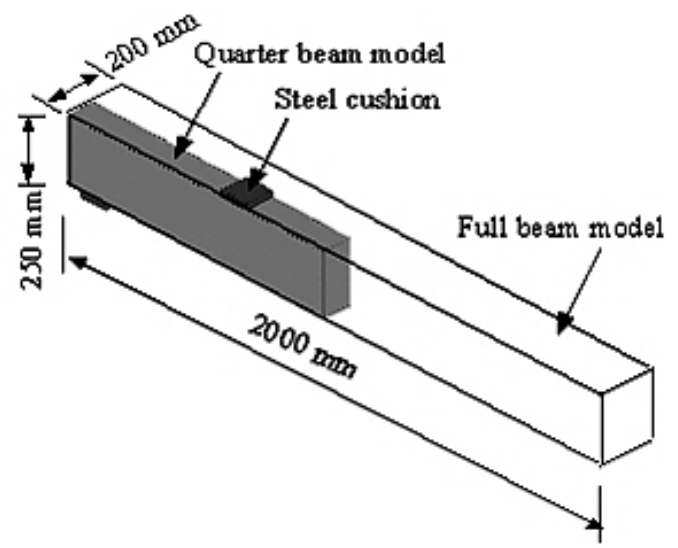

Fig. 2. Quarter beam model.

elements using discrete reinforcement modeling which is most preferred for RC elements with well defined reinforcement locations using E and EGEN commands. The support conditions were created using displacement (D) boundary conditions. The entire process of the nonlinear finite element analysis, such as geometrical modeling, material modeling, parameters for nonlinear analysis, creation of load-steps, graphical post processing of results, generation of various graphs and images and output in the form of text file was generated using a single input file developed using the APDL [4]. The FE model with discrete reinforcement model is shown in Fig. 3.

4. Modeling of Frictional Contact between the External Bar and Soffit of the Beam. The external bars behave in a hybrid of flexural and tied arch action, in addition to the frictional bonding by the soffit level external reinforced beams. The external bars also follow the deflected shape of the beam due to loading and frictional bonding increases due to load increase. This is one of the additional advantages of providing external bars at the soffit level when compared to the methods proposed by earlier researchers, in which the external bars were provided by the sides of the beam. The above behavior is incorporated in the model by the use of COMBIN39 element between the external bar and the soffit of the beam. COMBIN39 is a unidirectional element with nonlinear generalized force-deflection capability. The element has longitudinal or torsional capability. The longitudinal option is a uniaxial tension-compression element with up to three degrees of freedom at each node such as translations in the nodal $x, y$, and $z$ directions (ANSYS [4]). Displacement along $X$ and $Y$ axes were activated for the longitudinal and transverse COMBIN39 spring elements and all other options were set to default values. For incorporating the frictional bonding of longitudinal COMBIN39 elements, 5 percent of the bond strength of the fully bonded bar is assumed using IS 456: 2000 [16] nodal values. Since the external bars 


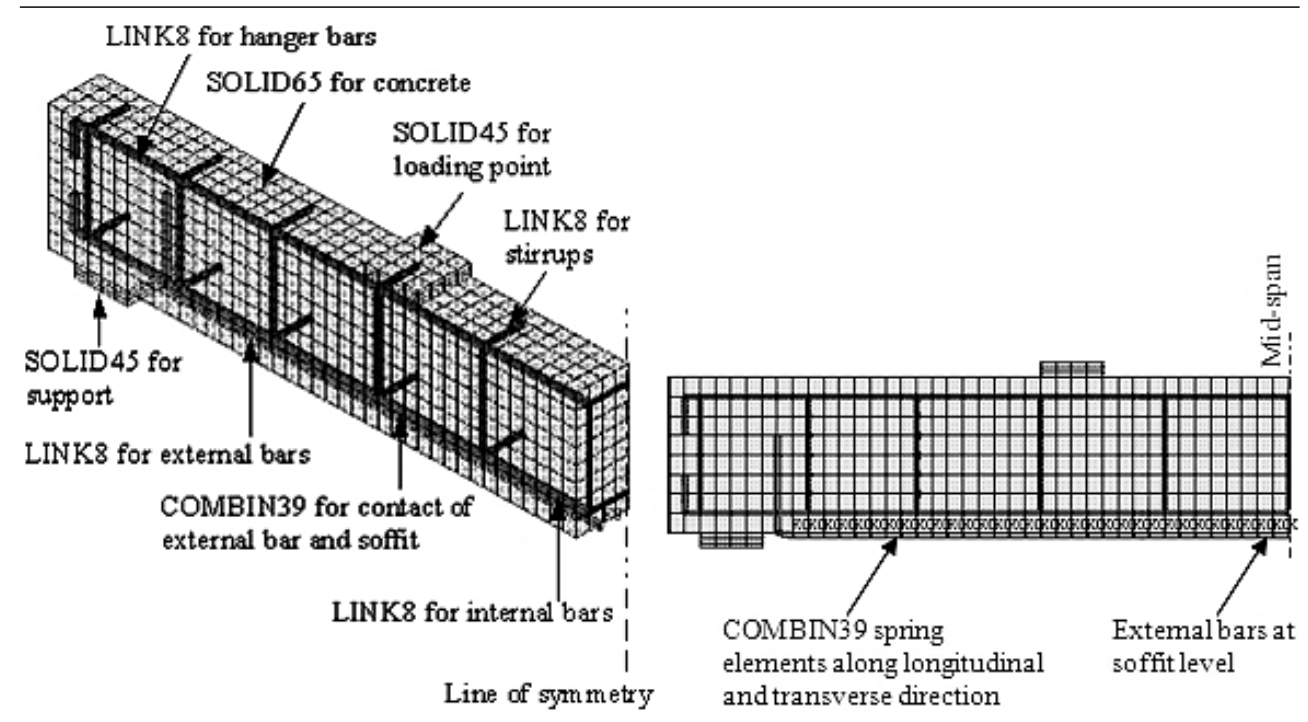

Fig. 3. FE model with reinforcement.

restrained to displace independently along the transverse direction by the contact of concrete elements a full stiffness using the modulus of elasticity of concrete is used for transverse COMBIN39 elements.

\section{Results and Discussion.}

5.1. Load-Deflection Behavior. Plots of load versus mid-span deflections obtained from experiment and FEA are depicted in Fig. 4 for beams in $\mathrm{N}$ and $\mathrm{H}$ series. The shape of the load-deflection plots are trilinear and immediately after the first crack formation, there is a small kink in the FEA plot, which is due to sudden loss of moment of inertia after the first crack formation. The comparison with experimental and FEA curves indicated that the experimental and FEA results are in good agreement.

5.2. Load versus Concrete Compressive Strain Behavior. Compressive strain values at the top compression face at mid-span section obtained from FEA are plotted and compared with experimental values and is depicted in Fig. 5 for beams in $\mathrm{N}$ and $\mathrm{H}$ series. The load versus compressive strain for the top compression face of the beams obtained by FEA is in good agreement with the experimental results.

5.3. Load versus Rebar Strain Behavior. The strain variations of the internal and external bars noted from FEA are compared with experimental values and are presented in Figs. 6 and 7. From the experimental investigations, it was noted that the strain observations of the internal bars were not recorded up to ultimate failure due to damage of the electrical strain gauges caused by crack formation and yielding of internal bars. The comparison of the plots shown in Figs. 6 and 7 indicated that the results of the FEA and experimental testing are in good agreement. The strain variation of the external bars showed that the yielding of the external bars occurs slightly at higher load when compared to internal bars. Hence, it is observed that even after the yielding of internal bars, the load carrying capacity was substantially increased due to the contribution by the external bars.

\subsection{Rebar Strain Variation along the Length of the Beam at Various Loading} Stages. Graphical display of axial strain variation along the length of the beam in internal and external bars for the beam specimens RF-H-10 and ER-H-10-10 at each load increments are depicted in Fig. 8. The strain in internal bars varies along the length of the beam with zero at the supports to maximum at the mid-span section in variation with bending moment values. Whereas, the strain in external bars remains uniform almost all along the length of the external bar due to lack of proper bonding along the length of bar. 

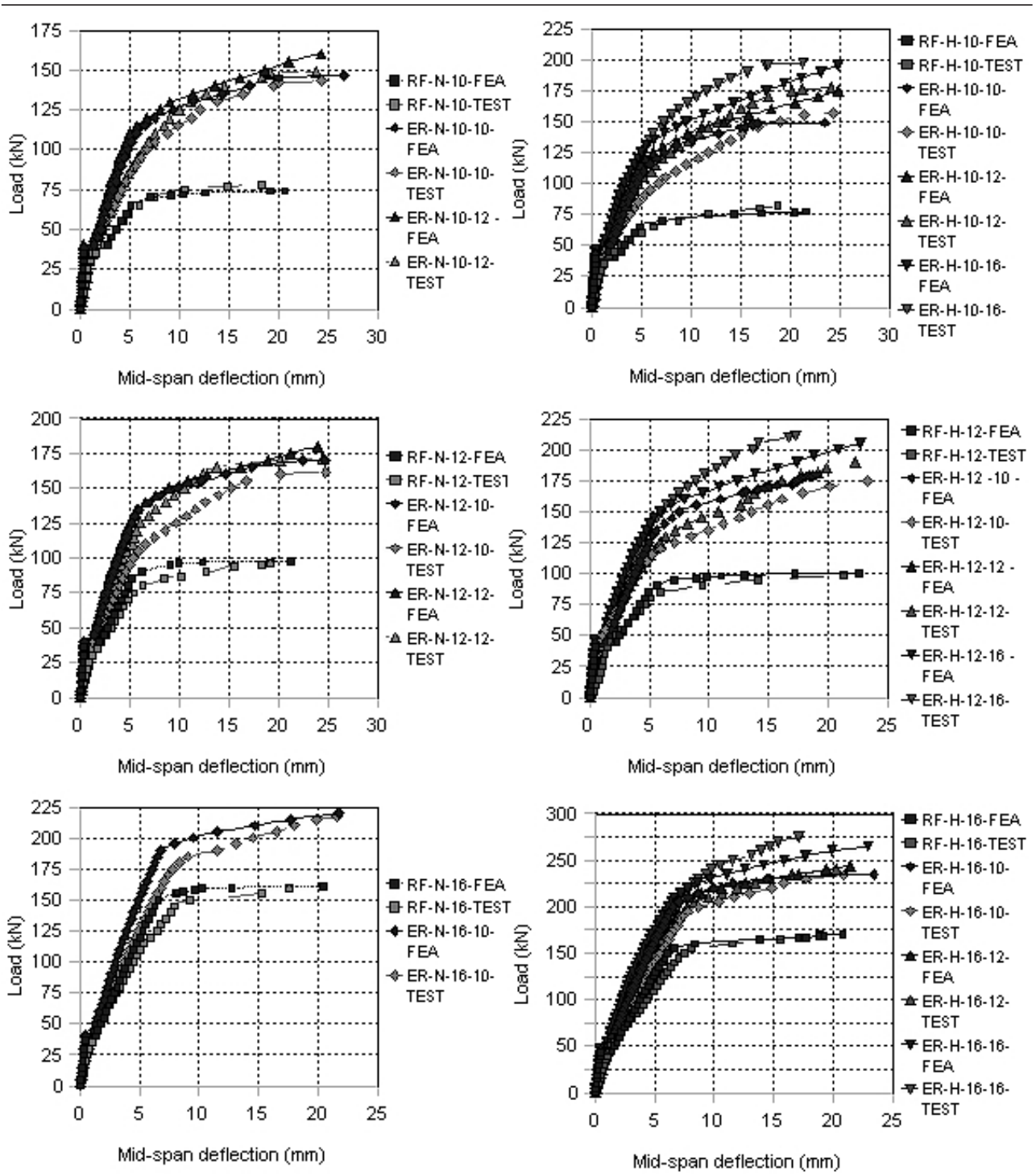

Fig. 4. Comparison of load versus mid-span deflection.

However, a small increase in external bar strain was noted towards the mid-span section of the beam due to frictional bonding. A small strain variation in the compression bar also depicted in Fig. 8. Similar observations were obtained for all the reference and retrofitted beams.

5.5. Cracking Behavior. Crack patterns developed during the experimental testing were keenly observed and marked on the beam and compared with cracking regions generated by FEA and are presented in Fig. 9. It is to be noted that the crack patterns generated by ANSYS are not the actual cracks but, the possible cracking regions. The loads at initial crack formation are keenly observed during the experimental testing and from FEA. The corresponding bending moment values calculated at initial crack formation in test and FEA are compared as indicated in Fig. 10 for all the beam specimens. It is to be noted that for the conventional beams (without external bars) the load at first crack essentially depends upon the strength of concrete. On the contrary, the provision of external 

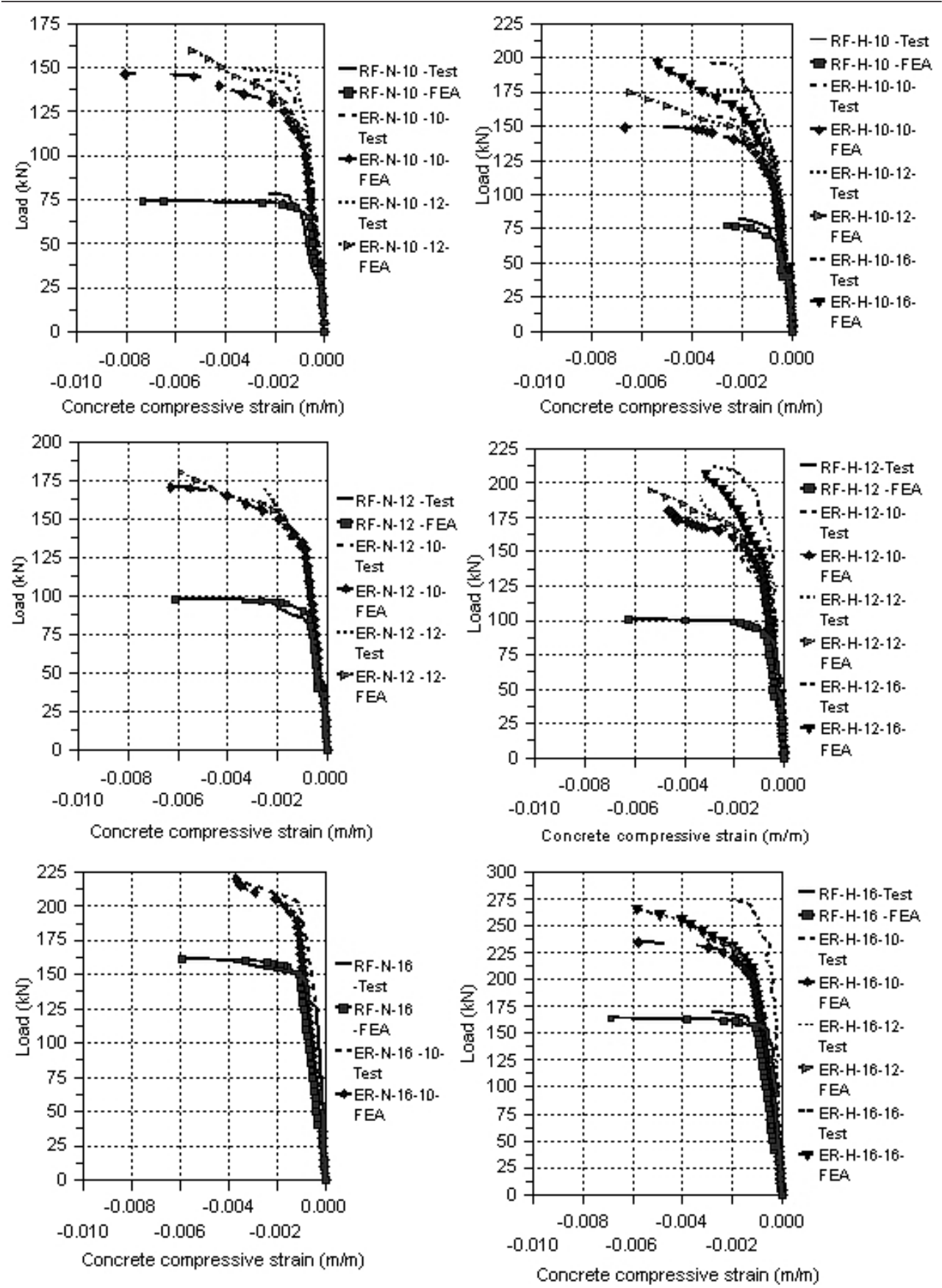

Fig. 5. Comparison of load versus concrete compressive strain.

bars has contributed significantly to enhance the load at initial crack formation. Improvement in the initial cracking behavior is mainly due to the hybrid of flexural and tied arch action in addition to the frictional bonding by the soffit level external reinforced beams. This is one of the additional advantages of providing external bars at the soffit of the beam. For the beam ER-H-16-16 with higher internal and external reinforcements the experimental initial cracking moment was higher by $64 \%$. 

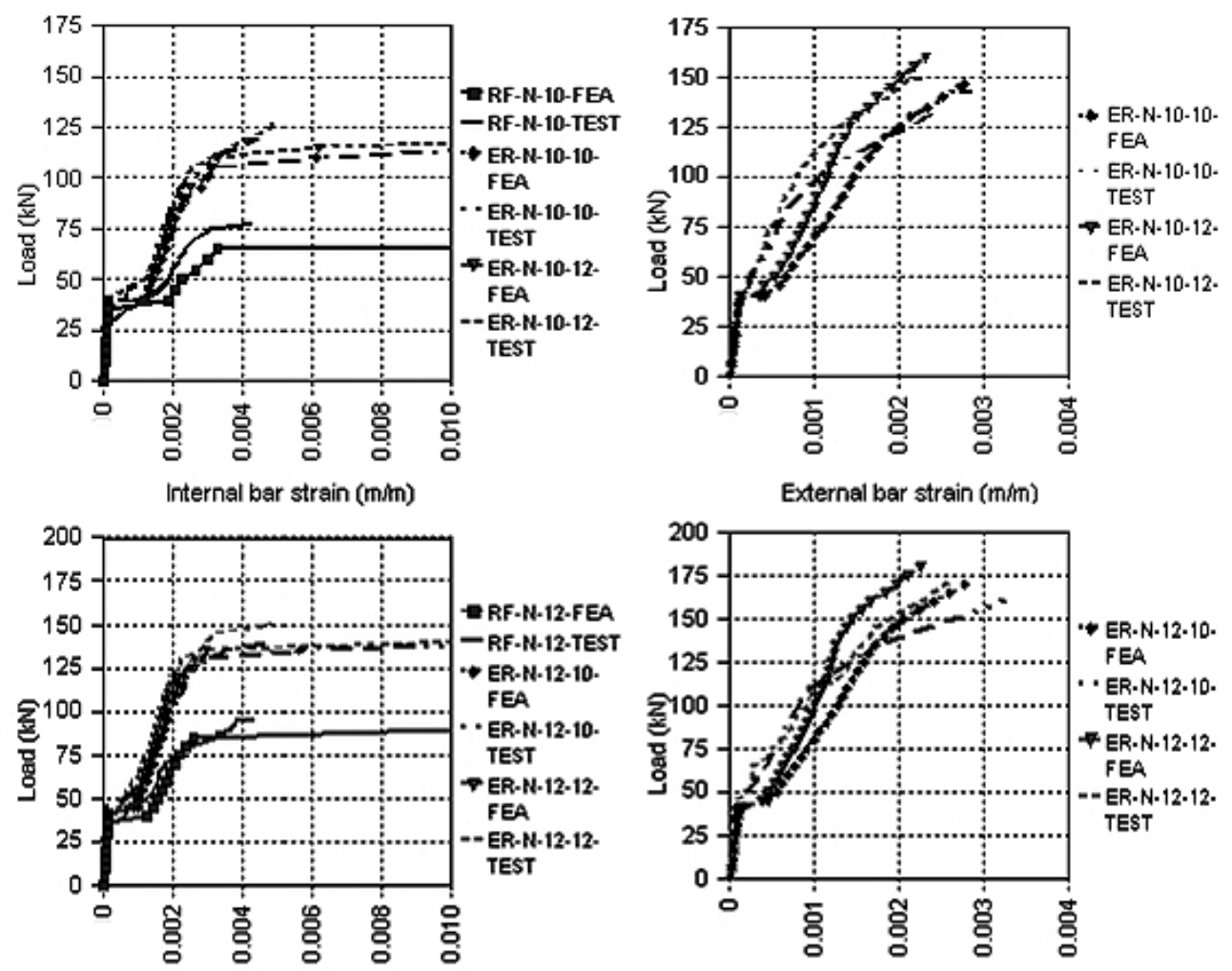

Internal bar strain (m/n)

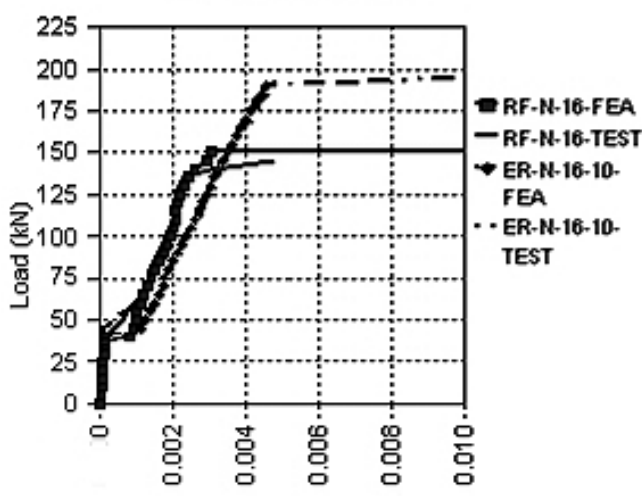

Internal bar strain (min)

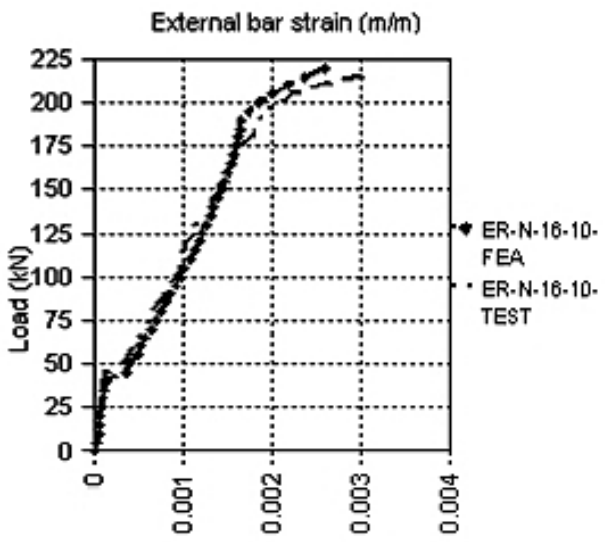

External bar strain (min)

Fig. 6. Comparison of load versus rebar strains (N-series).

5.6. The Ultimate Behavior. The ultimate load values obtained from FEA and experiments are compared as the ultimate moment as indicated in Fig. 11. The percentage increase in the ultimate capacity also varies with respect to grade of concrete, percentage of internal bars and external bar to internal ratio. It is also noted that the percentage increase in the ultimate moment capacity is higher for beams with lesser percentage of internal reinforcement. This clearly indicates that the external bars are more effective for lightly reinforced section than the heavily reinforced ones. The comparison between the experimental values and FEA results are in good agreement. 

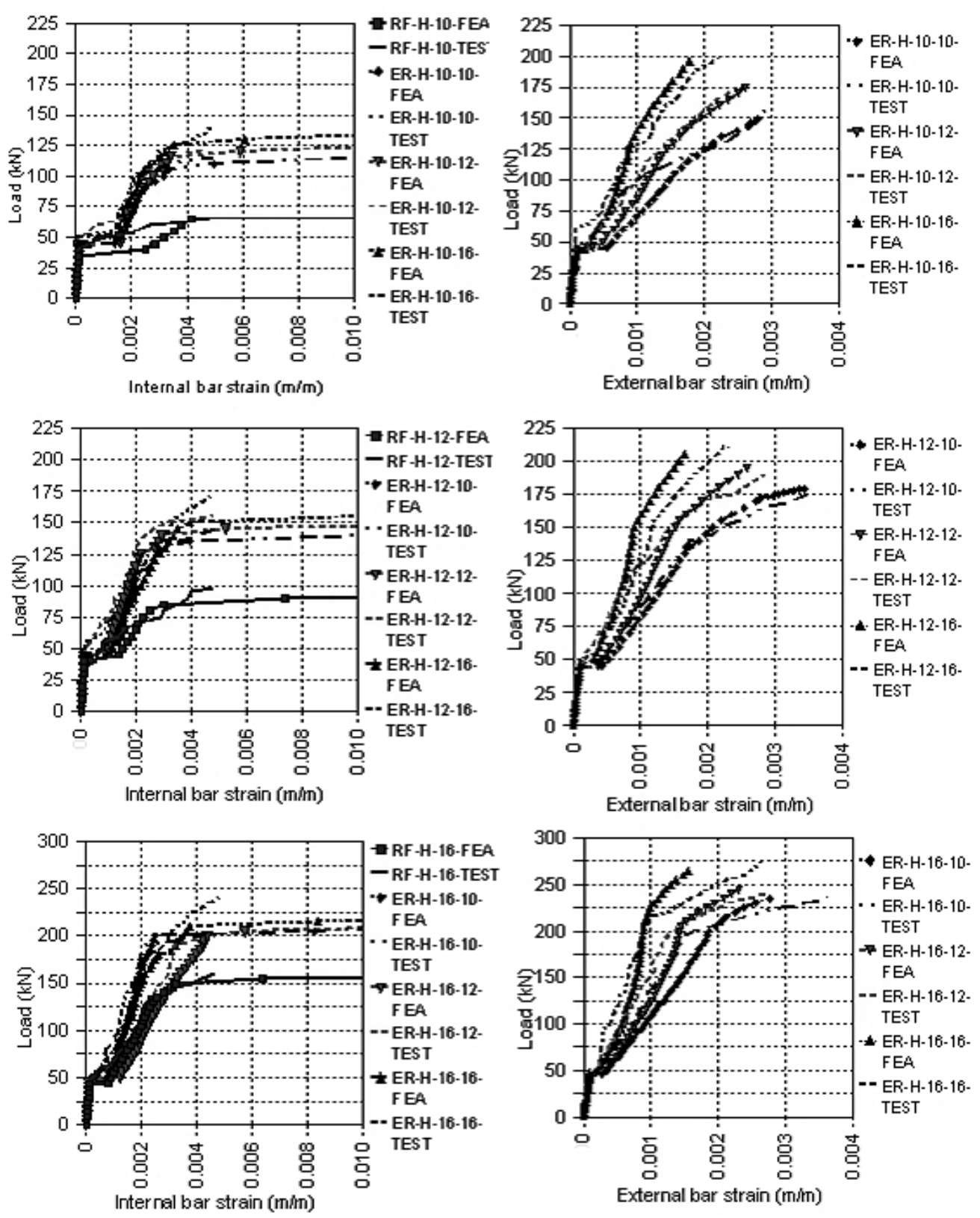

Fig. 7. Comparison of load versus rebar strains (H-series).

Conclusions. Based on the above nonlinear finite element analysis, six reference beam specimens and fourteen RC beam specimens retrofitted with external bars at the soffit level using ANSYS 12.0 and comparison with experimental results, the following conclusions are made.

1. Various plots constructed during FEA, such as load versus deflection behavior, load versus concrete compressive strain behavior, load versus axial strain in internal and external bars, axial strain variation along the length of internal and external the bars and crack patterns gives a broader view of the nonlinear behavior of $\mathrm{RC}$ beams with external bars at the soffit level. 


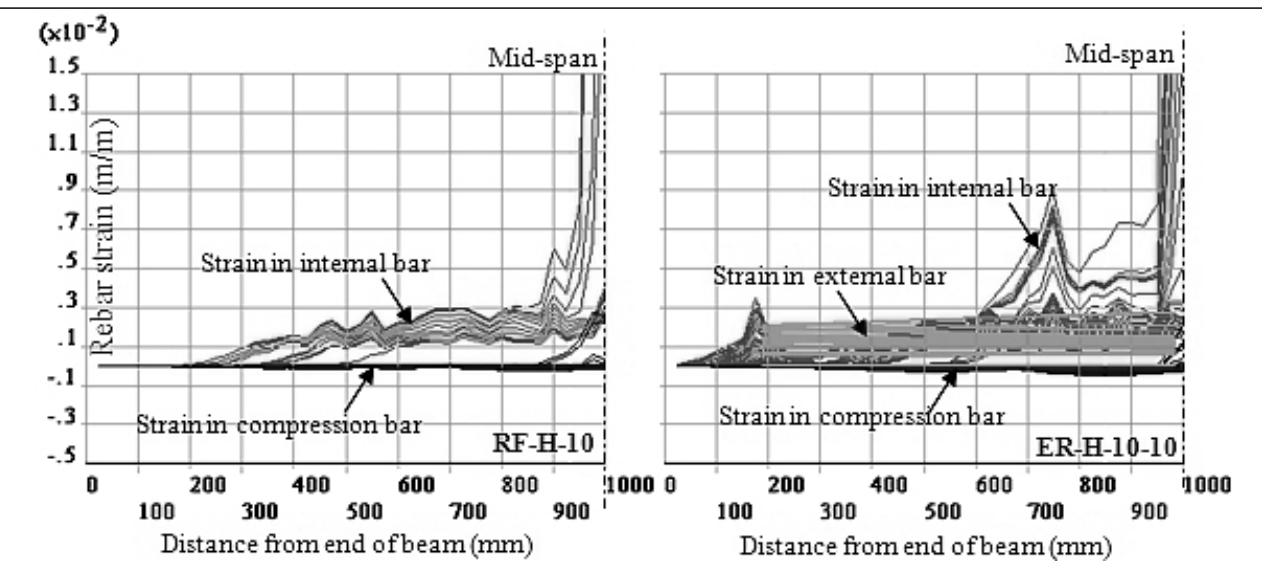

Fig. 8. Axial strain in internal, external, and compression bars.
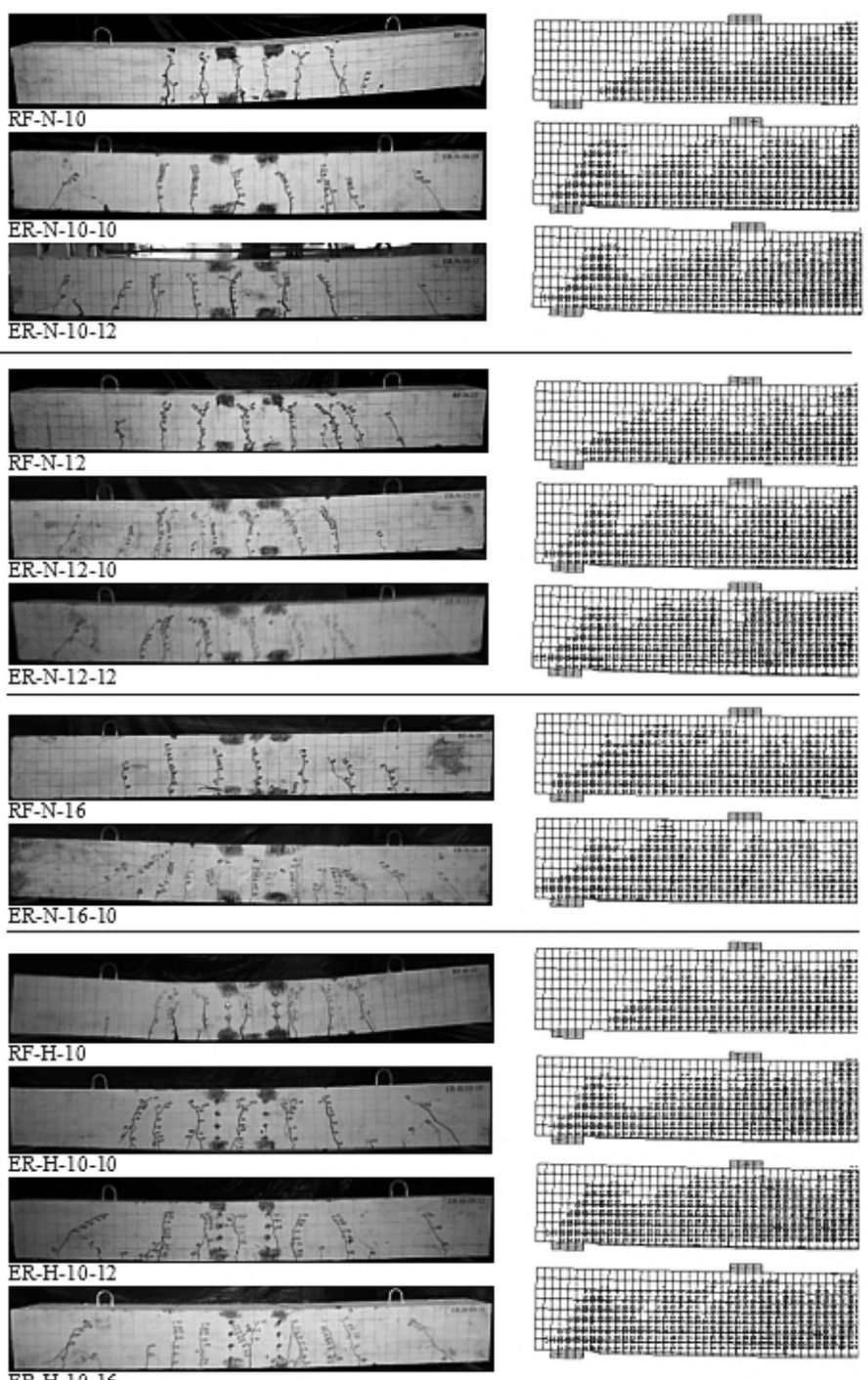

Fig. 9. Crack pattern from tests and FEA. 

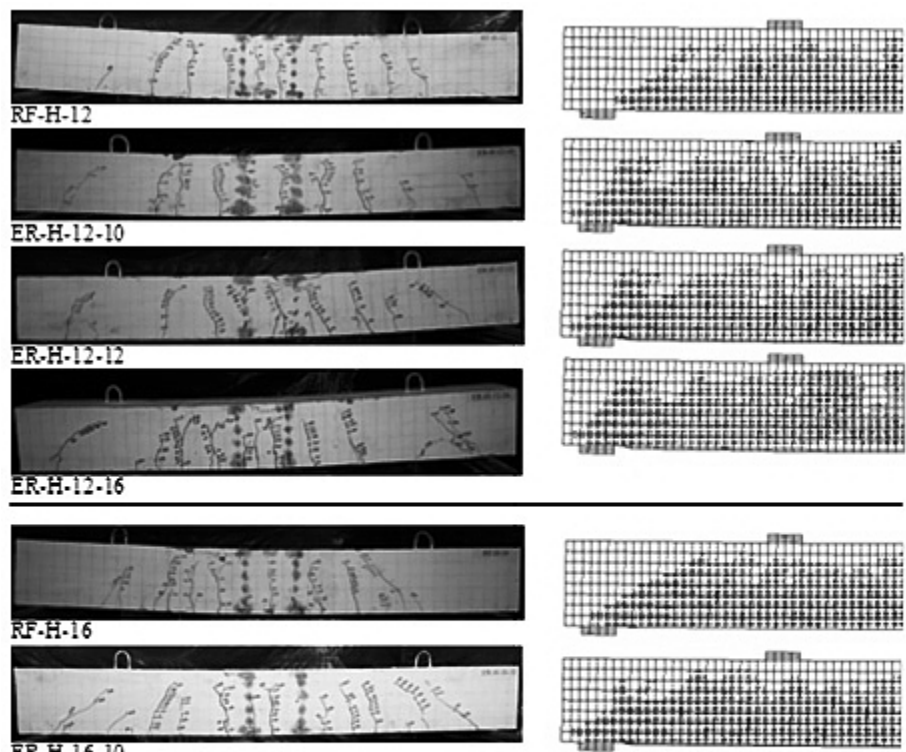

ER:H.16-10
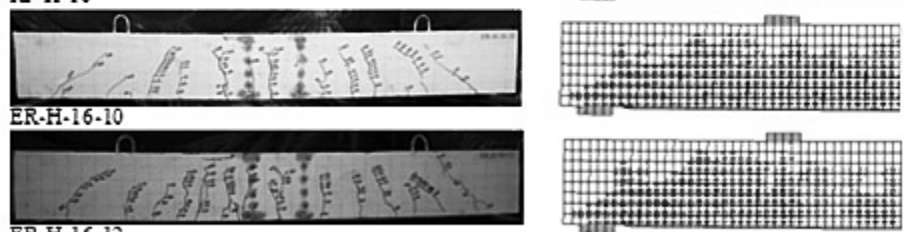

ER-H-16-12

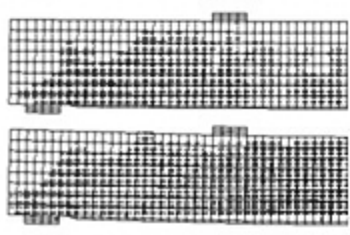

ER-H-16-16

Fig. 9 (continued). Crack pattern from tests and FEA.

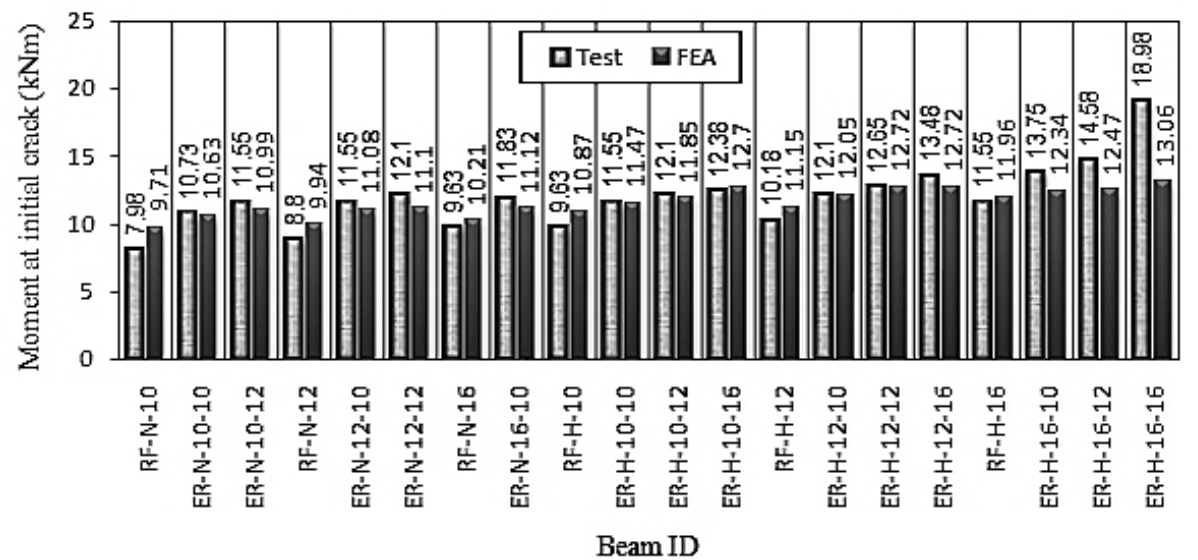

Fig. 10. Calculated and experimental moments at the initial crack formation instant.

2. Modeling of frictional contact between the external bars and the soffit of the beam using COMBIN39 spring elements along longitudinal and lateral direction provides reasonable results, which are in good agreement with test results.

3. The moment at initial crack formation and the ultimate moment obtained using FEA are in good agreement with test results.

4. The analysis procedure used in this paper and various output plots constructed by FEA has provided useful and deep insight for future application of finite element software for the nonlinear analysis of RC beams with external bars at the soffit level. 


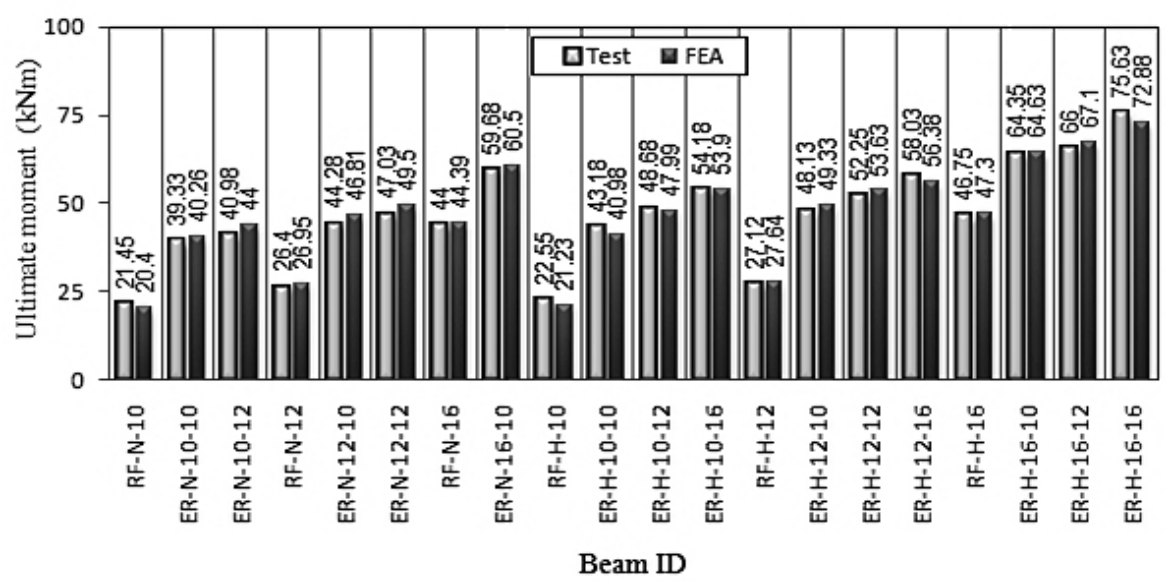

Fig. 11. Comparison of the ultimate moment.

\section{Резюме}

Одним з економічно ефективних і простих способів підвищення міцності при згині $\epsilon$ закріплення балки за допомогою зовнішніх стрижнів на рівні ії нижньої поверхні. Обговорюються моделювання методом скінченних елементів і нелінійний аналіз залізобетонних балок із додатковими арматурними стрижнями, виконані на базі програмного комплексу ANSYS 12.0. Моделювання методом скінченних елементів залізобетонних балок проводилось на основі дискретного моделювання армування. Отримані дані порівнювались із результатами експериментальних досліджень 20 зразків балки при чотириточковому згині. Для моделювання балки методом скінченних елементів використовувались елементи SOLID65, SOLID45 та LINK8. Наявність пружних елементів COMBIN39 дозволила змоделювати контакт тертя між нижньою поверхнею балки і зовнішніми стрижнями. Результати досліджень зігнутої форми балки, зміни деформації по іiі довжині і глибині та поширення тріщини на різних стадіях навантаження представлено у вигляді широкодіапазонного графічного дисплея за допомогою командного файла 3 використанням комплексу параметричного проектування ANSYS.

1. S. Kothandaraman and G. Vasudevan G, "Flexural retrofitting of RC beams using external bars at soffit level - An experimental study," Constr. Build. Mater., 24, No. 11, 2208-2216 (2010).

2. T. Hassan and S. Rizkalla, "Investigation of bond in concrete structures strengthened with near surface mounted carbon fiber reinforced polymer strips," J. Compos. Construct., 7, No. 3, 248-257 (2003).

3. H. Thomsen, E. Spacone, S. Limkatanyu, and G. Camata, "Failure mode analyses of reinforced concrete beams strengthened in flexure with externally bonded fiberreinforced polymers," J. Compos. Construct., 8, No. 2, 123-131 (2004).

4. ANSYS Commands Reference, ANSYS, http://www.ansys.com (2005).

5. E. R. Buckhouse, External Flexural Reinforcement of Existing Reinforced Concrete Beams Using Bolted Steel Channels, Master's Thesis, Marquette University, Milwaukee, WI (1997).

6. A. J. Wolanski, Flexural Behavior of Reinforced and Prestressed Concrete Beams Using Finite Element Analysis, Master's Thesis, Marquette University, WI (2004). 
7. D. Kachlakev, T. Miller, S. Yim, et al., Finite Element Modeling of Reinforced Concrete Structures Strengthened with FRP Laminates, Final Report, SPR 316, Oregon Dept. of Transportation, Washington, DC (2001).

8. P. Fanning, "Nonlinear models of reinforced and post-tensioned concrete beams," Electr. J. Struct. Eng., 2, 111-119 (2001).

9. L. Dahmani, A. Khennane, and S. Kaci, "Crack identification in reinforced concrete beams using ANSYS software," Strength Mater., 42, No. 2, 232-240 (2010).

10. F. A. Tavarez, Simulation of Behaviour of Composite Grid Reinforced Concrete Beams Using Explicit Finite Element Methods, Master's Thesis, University of Wisconsin-Madison, Madison, WI (2001).

11. G. Vasudevan and S. Kothandaraman, "Behaviour prediction of RC beams Comparison of experimental, FEA and analytical methods," in: Proc. of the IEEE-Int. Conf. on Advances in Engineering, Science, and Management (Nagapattinam, India) (2012), pp. 365-370.

12. H. E. M. Sallam, A. A. Badawy, M. M. Balaha, et al., "Finite element analysis of peeling failure in strengthened RC beams by CFRP plates," The Egyptian Int. J. Eng. Sci. Technol., 12, No. 2, 25-36 (2009).

13. S. Elavenil and V. Chandrasekar, "Analysis of reinforced concrete beams strengthened with ferrocement," Int. J. Appl. Eng. Res., 2, No. 3, 431-440 (2007).

14. R. Santhakumar, E. Chandrasekaran, and R. Dhanaraj, "Behaviour of retrofitted reinforced concrete beams under combined bending and torsion: A numerical study," Electr. J. Struct. Eng., 7, 1-7 (2007).

15. G. Vasudevan and S. Kothandaraman, "Parametric study on nonlinear finite element analysis on flexural behaviour of RC beams using ANSYS," Int. J. Civil Struct. Eng., 2, No. 1, 98-111 (2011).

16. IS 456: 2000. Indian Standard: Plain and Reinforced Concrete - Code of Practice, Bureau of Indian Standards, New Delhi (2000). 